\title{
Legalizing Harm Reduction
}

\author{
AILA Hoss* \\ TABLE OF CONTENTS
}

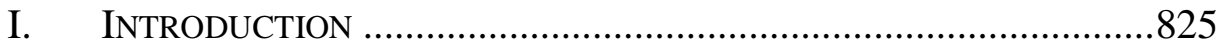

II. UNDERSTANDING HARM REDUCTION .......................................8229

III. HARM REDUCTION LAWS IN THE UNITED STATES ......................832

A. Syringe Service Programs...............................................833

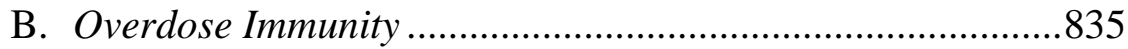

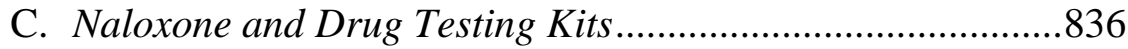

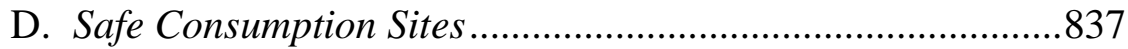

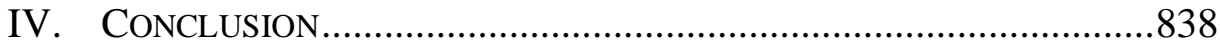

\section{INTRODUCTION}

The opioid use disorder and overdose crisis continues to challenge our agencies, institutions, and the laws underpinning our public health, healthcare, and criminal justice systems. ${ }^{1}$ Recent data from the Centers for Disease Control and Prevention indicate that the rates of drug overdose have increased in many parts of the country. ${ }^{2}$ While many overdoses are opioid-related, ${ }^{3}$ parts of the country have seen increases in the use of methamphetamine and cocaine. ${ }^{4}$ Drug

\footnotetext{
* Aila Hoss is a Visiting Assistant Professor at Indiana University McKinney School of Law. Her research explores topics in public health law, health policy development, and the impact of federal Indian law and Tribal law on health outcomes. The author would like to thank the faculty, staff, and students at Ohio State University Moritz College of Law for graciously hosting this symposium. The author is also indebted to the student editors of the Ohio State Law Journal for their editorial assistance. Finally, the author also thanks Michael Brewer, Joshua Jones, Anthony Singer, and Nicolas Terry for their comments on this Article.

${ }^{1}$ See Nicolas P. Terry et al., Legal and Policy Best Practices in Response to the Substance Abuse Crisis: A Preliminary Report 17-18 (2018), https://scholarworks.iupui.edu/bitstream/handle/1805/15972/iu-grand-challengeslegal-and-policy-best-practices.pdf;jsessionid=B4025DDAC7A9912D51E86AF2F3C 56D6B? sequence=1 [https://perma.cc/W8JW-ZDUM].

${ }^{2}$ Drug Overdose Deaths, CTRS. FOR DiseAse CONTROL \& PREVEnTION (last updated Dec. 19, 2018), https://www.cdc.gov/drugoverdose/data/statedeaths.html [https:// perma.cc/PJ5U-B78Y] (outlining the CDC's findings on drug overdoses).

${ }^{3}$ Puja Seth et al., Overdose Deaths Involving Opioids, Cocaine, and Psychostimulants-United States, 2015-2016, CTRS. FOR DISEASE CONTROL AND Prevention: Morbidity AND Mortality WeEkly ReP. (Mar. 30, 2018), https://www.cdc.gov/mmwr/volumes/67/wr/mm6712a1.htm?scid=mm6712a1_w [https://perma.cc/XU95-K2HC] (discussing the amount of opioid-related overdose deaths in the United States).

${ }^{4}$ Austin Frakt, Overshadowed by the Opioid Crisis: A Comeback by Cocaine, N.Y. TIMES (Mar. 5, 2018), https://www.nytimes.com/2018/03/05/upshot/ overshadowedby-the-opioid-crisis-acomeback-by-cocaine.html [https://perma.cc/ 498B-4L6F] (elaborating on the surge in cocaine related deaths); Anna Gorman,
} 
overdose has now surpassed motor vehicle-related deaths as the leading cause of death in many states. ${ }^{5}$ Overdose deaths are only one of many tragedies associated with substance use disorder. Substance use disorder is associated with illnesses such as HIV, Hepatitis C, and chronic kidney disease, among others. ${ }^{6}$

In addition to poor health outcomes experienced by individuals with opioid use disorder, the crisis has strained the economy and the criminal justice system. ${ }^{7}$ A 2018 report found that the cost of the opioid crisis from 2001 to 2017 exceeded $\$ 1$ trillion in the form of lost wages, lost productivity, lost tax revenue, as well as government spending on health care, social services, education, and criminal justice. ${ }^{8}$ A 2013 study found that over a third of this cost comes in the form of increased health care expenditures. ${ }^{9}$ In its civil lawsuit against an opioid manufacturer, the State of New Jersey estimated that its Medicaid vendors, workers' compensation program, and employee and retiree health plans have spent \$290 million in opioid-related costs. ${ }^{10}$ Similarly, the City of Tacoma estimated its spending has increased $\$ 10$ million a year as a result of the opioid crisis. ${ }^{11}$

Children and families are also among the victims of the opioid use disorder crisis. ${ }^{12}$ Families are split up when loved ones are in prison for opioid-related

Overshadowed by Opioids, Meth Is Back and Hospitalizations Surge, KAISER HEALTH NEWS (Nov. 26, 2018), https://khn.org/news/overshadowed-by-opioids-meth-is-back-andhospitalizations-surge/ [https://perma.cc/2TQF-YCA6] (describing the rise of meth usage).

${ }^{5}$ M. Reidhead \& L. Porth, A Dangerous Intersection: Drug Overdose Fatalities Surpass Motor Vehicle Deaths, Mo. HosP. Ass'N (2018), https://www.mhanet.com/ mhaimages/opioid/MVA_v_Opioids/A_Dangerous_Intersectin.pdf [https://perma.cc/ $768 X-B L K L]$ ("Throughout the past 16 years, the list of states with more deaths caused by drug overdoses than motor vehicles has grown from four to 39.").

${ }^{6}$ Eric Sarlin, Substance Use Disorders Are Associated with Major Medical Illnesses and Mortality Risk in a Large Integrated Health Care System, NAT'L INST. ON DRUG ABUSE (Oct. 24, 2017), https://www.drugabuse.gov/news-events/nida-notes/2017/10/ substanceuse-disorders-are-associated-major-medical-illnesses-mortality-risk-inlarge-integrated [https://perma.cc/B2SK-83FX].

7 TERRY ET AL., supra note 1, at 9, 18.

${ }^{8}$ Economic Toll of Opioid Crisis in U.S. Exceeded \$1 Trillion Since 2001, Altarum (Feb. 13, 2018), https://altarum.org/about/news-and-events/economic-toll-ofopioidcrisis-in-u-s-exceeded-1-trillion-since-200 [https://perma.cc/RL2A-ZSVM] (reporting the current costs of the opioid crisis and projecting future expenditures).

${ }^{9}$ Curtis S. Florence et al., The Economic Burden of Prescription Opioid Overdose, Abuse, and Dependence in the United States, 2013, 54 MED. CARE 901, 901 (2016).

${ }^{10}$ Complaint at 7, Porrino v. Purdue Pharma, L.P. (N.J. Super. Ct. Ch. Div. Essex County Oct. 31, 2017), https://nj.gov/oag/newsreleases 17/NJ-Purdue-Complaint_ Redacted_final.pdf [https://perma.cc/BH4F-N2WZ].

${ }^{11}$ Complaint at 63, City of Tacoma v. Purdue Pharma, L.P., No. 3:17-cv-5737 (W.D. Wash. Sept. 13, 2017).

${ }^{12}$ See generally Yuki Noguchi, Anguished Families Shoulder the Biggest Burdens of Opioid Addiction, NPR (Apr. 18, 2018), https://www.npr.org/2018/04/18/602826966/ 
charges, when individuals are seeking treatment, or after an overdose death. ${ }^{13}$ Foster care systems are unable to meet the growing demand of placing children in foster care families. ${ }^{14}$ Indiana, for example, has seen the number of children in foster care increase by thousands. ${ }^{15}$ Many parents with opioid use disorder are imprisoned from drug-related criminal charges, which can have downstream health effects on their children. ${ }^{16}$ The Adverse Childhood Experience (ACE) Questionnaire is a tool to assess childhood trauma, such as abuse and neglect. ${ }^{17}$ High ACE scores are associated with poor health outcomes, including chronic disease and early death. ${ }^{18}$ The questionnaire includes a question on whether the child has had a parent in prison, ${ }^{19}$ a trauma for the child which can lead to increased risk of substance use disorder. ${ }^{20}$

The root causes of the opioid use disorder and overdose crisis are complex and necessitate comprehensive changes to our social, health care, and criminal justice systems, which would take significant time to implement. ${ }^{21}$ Yet there are interventions that can be implemented to curb overdoses and other poor health

anguished-families-shoulder-the-biggestburdens-of-opioid-addiction [https://perma. cc/P2LL-FJVG] (explaining how opioid addiction tears apart families in the United States).

${ }^{13}$ See id.; Laura Radel et al., Substance Use, the Opioid Epidemic, and the Child Welfare System: Key Findings from a Mixed Methods Study, U.S. DeP'T HeALTH \& HuM. SERVS. 3 (Mar. 7, 2018), https://aspe.hhs.gov/system/files/pdf/258836/SubstanceUse ChildWelfareOverview.pdf [https://perma.cc/KG2V-W8VZ] ("Higher rates of overdose deaths and drug hospitalizations correspond with higher child welfare caseload rates.").

${ }^{14}$ Scott Simon, The Foster Care System Is Flooded with Children of the Opioid Epidemic, NPR (Dec. 23, 2017), https://www.npr.org/2017/12/23/573021632/thefoster-care-system-is-flooded-with-children-of-the-opioidepidemic [https://perma.cc/ $6 \mathrm{~K} 3 \mathrm{R}-8 \mathrm{~F} 2 \mathrm{~S}$ ] (describing difficulties in placing and affording the number of children entering the system).

${ }^{15} I d$.

${ }^{16}$ See About Adverse Childhood Experiences, CTRS. FOR DISEASE CONTROL \& PREVENTION (Apr. 9, 2019), https://www.cdc.gov/violenceprevention/childabuseand neglect/acestudy/aboutace.html [https://perma.cc/ZNM4-Z7QH]; Adverse Childhood Experience (ACE) Questionnaire, NAT'L COUNCIL JUV. \& FAM. CT. JUDGES, https://www. ncjfcj.org/sites /default/files/Finding\%20Your\%20ACE\%20_Score.pdf [https://per ma.cc/LG7C-ULGP] [hereinafter ACE Questionnaire].

17 See ACE Questionnaire, supra note 16.

${ }^{18}$ Id.

${ }^{19} \mathrm{Id}$.

${ }^{20}$ The Role of Adverse Childhood Experiences in Substance Abuse and Related Behavioral Health Problems, SAMHSA's CTR. FOR APPLICATION PREVENTION TECHS., https://www.cambridgema.gov/CDD/Projects/Planning/ /media/328D3B716 A24449D8504357BD3865949.ashx [https://perma.cc/7KM2-ZBCL].

21 See generally Nabarun Dasgupta et al., Opioid Crisis: No Easy Fix to Its Social and Economic Determinants, 108 AM. J. PUB. HEALTH 182 (2018) (proposing suggestions to address the structural problems causing the opioid crisis); Nicolas P. Terry, Structural Determinism Amplifying the Opioid Crisis: It's the Healthcare, Stupid!, 11 NE. U. L. REV. 315 (2019) (discussing the failings of the healthcare system in relation to the opioid epidemic). 
outcomes associated with substance use immediately. ${ }^{22}$ Namely, harm reduction.

Harm reduction refers to public health strategies that seek to minimize the injury and illness associated with substance use, as opposed to eliminating substance use itself. ${ }^{23}$ For example, in the context of opioid use, harm reduction strategies can include increased naloxone training and availability to prevent overdose $^{24}$ or establishing syringe service programs to allow people who inject drugs to have access to unused syringes, thereby reducing their risk of transmission of HIV, Hepatitis C, and skin infections ${ }^{25}$ from the sharing and reuse of needles. ${ }^{26}$

Harm reduction strategies have seen increased prominence in the United States as the opioid overdose crisis unfolded. But implementation has been inconsistent and fragmented in some jurisdictions without adequate policy development to ensure their efficacy. ${ }^{27}$ This Article argues that it is long overdue for harm reduction strategies to be legalized with enabling authorities to ensure they are effective in practice.

Part I provides background on harm reduction by describing select harm reduction strategies and the evidence base for them. Part II discusses the status of harm reduction in the United States by describing four harm reduction strategies in more detail. It discusses how the legal frameworks for these strategies could be improved in some jurisdictions. Part III concludes by outlining changes in law that are necessary to legalize harm reduction that would create a path towards legalization of drugs.

${ }^{22}$ Reducing the Harm of Drug Use and Dependence, UNITED NATIONS OFF. ON DRUGS \& CRIME: TREAT NET, https://www.unodc.org/ddt-training/treatment/VOLUME\%20D/ Topic\%204/1.VolD_Topic4_Harm_Reduction.pdf [https://perma.cc/E8RP-RSBJ].

${ }^{23} \mathrm{Id}$.

${ }^{24}$ Daniel Kim et al., Expanded Access to Naloxone: Options for Critical Response to the Epidemic of Opioid Overdose Mortality, 99 Am. J. Pub. Health 402, 405 (2009).

${ }^{25}$ See generally John R. Ebright \& Barbara Pieper, Skin and Soft Tissue Infections in Injection Drug Users, in 16 INFECTIOUS DISEASE CLINICS OF NORTH AMERICA 697 (Robert C. Moellering, Jr. ed., 2002) (discussing the skin infections drug users may experience due to a combination of tissue trauma, the drug itself, and bacteria).

${ }^{26}$ See, e.g., Holly Hagan et al., Reduced Risk of Hepatitis B and Hepatitis C Among Injection Drug Users in the Tacoma Syringe Exchange Program, 85 AM. J. Pub. HeALth 1531, 1531 (1995); Don C. Des Jarlais et al., HIV Incidence Among Injecting Drug Users in New York City Syringe-Exchange Programmes, 348 LANCET 987, 987 (1996); Gregg S. Gonsalves \& Forrest W. Crawford, Dynamics of the HIV Outbreak and Response in Scott County, IN, USA, 2011-15: A Modelling Study, 5 LANCET e569, e569 (2018), https://www.thelancet.com/pdfs/journals/lanhiv/PIIS2352-3018(18)30176-0.pdf [https://perma.cc/XE2J-EVG3]; Alex Wodak \& Annie Cooney, Effectiveness of Sterile Needle and Syringe Programming in Reducing HIV/AIDS Among Injecting Drug Users, WHO (2004), https://www.who.int/hiv/pub/prev_care/effectivenesssterileneedle.pdf [https://perma.cc/R4N5-QYLU] [hereinafter Wodak \& Cooney].

27 TERRY ET AL., supra note 1, at 20-21 (explaining how piecemeal implementation has impacted the state of Indiana). 


\section{UNDERSTANDING HARM REDUCTION}

The origins of modern harm reduction in the United States are rooted in the prohibition and criminalization of drugs. ${ }^{28}$ As drug use went underground to avoid criminal liability, individuals who used drugs and their allies needed to establish methods to utilize these substances safely. ${ }^{29}$ Particularly following the HIV/AIDS epidemic in the 1980s, harm reduction strategies have been mainstreamed as effective prevention strategies for infectious disease amongst medical and public health communities. ${ }^{30}$

Researchers have made distinctions regarding the types and justifications for harm reduction strategies. ${ }^{31}$ A public health model for harm reduction seeks to justify these strategies purely from a disease prevention approach. ${ }^{32} \mathrm{~A}$ human rights model for harm reduction justifies these strategies because drug users are deserving of the health care, safety, and freedoms of other members of the public, often denied because of the criminalization of drug use. ${ }^{33}$

Harm reduction principles have been applied in policies and programs outside of illicit drug use, including tobacco use, ${ }^{34}$ alcohol use, ${ }^{35}$ and sexual health education, ${ }^{36}$ among others. Within these issues, examples include ecigarettes as a tool to reduce the harm of combustible cigarettes, ${ }^{37}$ wet shelters and housing as a tool to limit the health harms of homelessness, ${ }^{38}$ and contraception access and education as a tool to reduce unintended pregnancies

${ }^{28}$ Don C. Des Jarlais, Harm Reduction in the USA: The Research Perspective and an Archive to David Purchase, 14 HARM REDUCTION J. 51, 52 (2017), https://harm reductionjournal.biomedcentral.com/track/pdf/10.1186/s12954-017-0178-6 [https:// perma.cc/3GYD-XK5Q].

${ }^{29}$ Gordon Roe, Harm Reduction as Paradigm: Is Better than Bad Good Enough? The Origins of Harm Reduction, 15 CRITICAL PUB. HEALTH 243, 243 (2005).

${ }^{30}$ Id.

31 Id.

${ }^{32}$ Id. at 245; Christopher B.R. Smith, Harm Reduction Hipsters: Socio-SpatialPolitical Displacement and the 'Gentrification of Public Health', in CRITICAL APPROACHES TO HARM REDUCTION 209, 211-12 (Christopher Smith \& Zack Marshall eds., 2016).

33 Id. at 223.

${ }^{34}$ Caitlin Notley et al., The Unique Contribution of E-Cigarettes for Tobacco Harm Reduction in Supporting Smoking Relapse Prevention, 15 HARM REDUCTION J. 31, 31 (2018), https://harmreductionjournal.biomedcentral.com/track/pdf/10.1186/s12954 018-0237-7 [https://perma.cc/G6NF-7ATH].

35 G. Alan Marlatt \& Katie Witkiewitz, Harm Reduction Approaches to Alcohol Use: Health Promotion, Prevention, and Treatment, 27 Addictive BeHAVs. 867, 867 (2002).

${ }^{36}$ Karen Mary Leslie, Harm Reduction: An Approach to Reducing Risky Health Behaviours in Adolescents, in 13 PAEDIATRIC CHILD HEAlth 53, 53 (2008), https://www.ncbi.nlm.nih.gov/pmc/articles/PMC2528824/pdf/pch13053.pdf [https:// perma.cc/M7D9-UFE8].

37 Notley et al., supra note 34 , at 31 .

38 Tina Rosenberg, The Shelter that Gives Wine to Alcoholics, GUARDIAN (Apr. 26, 2016), https://www.theguardian.com/society /2016/apr/26/homeless-shelterottawagives wine-to-alcoholics [https://perma.cc/6XGA-FW8C]. 
and sexually transmitted infections. ${ }^{39}$ Harm reduction acknowledges that it is impossible to eliminate all health harms and instead seeks to reduce the harms associated with an activity. ${ }^{40}$

Harm reduction strategies have been studied extensively in the context of drug use, particularly injectable drug use, largely due to the HIV crisis in the 1980s but also due to the current opioid crisis facing the United States. ${ }^{41}$ Examples of selected harm reduction strategies used to respond to the opioid epidemic and their evidence base are outlined below.

A variety of harm reduction strategies are available to fight the opioid crisis. Syringe service programs (SSPs), for example, gained prominence in the 1980s to reduce the spread of HIV among people who inject drugs (PWID). ${ }^{42}$ These programs provide a location where PWID can securely dispose of used syringes and secure unused syringes without cost for future use. ${ }^{43}$ SSPs also often provide other resources and services such as safe injection practices and linkages to treatment. ${ }^{44}$ Importantly, SSPs are often one of the few locations where PWID can come as they are without judgment or stigma. ${ }^{45}$ The evidence base for syringe service programs spans several decades. ${ }^{46}$ Areas with syringe service programs have seen a reduction of bloodborne disease transmission, such as HIV and Hepatitis C. ${ }^{47}$ Amongst PWID, evidence indicates that there is a reduction in the injection-related risk behaviors, such as sharing syringes, and a decrease in the number of times a syringe was reused. ${ }^{48}$ SSPs have also served as a vehicle to link individuals with substance use disorder (SUD) to other services, including initiating treatment. ${ }^{49}$ From a funding standpoint, investments in SSPs are less costly than the alternative of providing healthcare

${ }^{39}$ Leslie, supra note 36 , at $53,55$.

${ }^{40}$ Id. at 53.

${ }^{41}$ Des Jarlais, supra note 28.

42 See generally Don C. Des Jarlais, Mathilde Krim, AmfAR, and the Prevention of HIV Infection Among Injecting Drug Users: A Brief History, 20 AIDS PATIENT CARE \& STDS 467 (2006).

${ }^{43}$ Syringe Exchange Programs-United States, 2008, CTRS. FOR DISEASE CONTROL \& PREVENTION: MORBIDITY \& MORTALITY WKLy. ReP. (Nov. 19, 2010) https://www.cdc.gov/mmwr/preview/mmwrhtml $/ \mathrm{mm} 5945 \mathrm{a} 4 . \mathrm{htm}$ ?s_cid=mm5945a4w [https://perma.cc/Q59Y-SBB9] (explaining the services syringe exchange programs can provide to people who inject drugs).

${ }^{44}$ Id.

45 TERRY ET AL., supra note 1, at 29.

46 See Wodak \& Cooney, supra note 26, at 5.

47 See, e.g., Hagan et al., supra note 26, at 1531.

${ }^{48}$ Monita R. Patel et al., Reduction of Injection-Related Risk Behaviors After Emergency Implementation of a Syringe Services Program During an HIV Outbreak, 77 J. ACQUIRED IMMUNE DEFICIENCY SYNDROMES 373, 373 (2018) ("Sterile syringe access as part of comprehensive HIV prevention is an important tool to control and prevent HIV outbreaks.").

${ }^{49}$ Steffanie A. Strathdee et al., Needle-Exchange Attendance and Health Care Utilization Promote Entry into Detoxification, 76 J. URB. HeAlth 448, 448 (1999). 
for HIV and Hepatitis C. ${ }^{50}$ Those opposed to SSPs state that SSPs lead to higher rates of crime and increased drug use; ${ }^{51}$ however, evidence does not indicate that this is the case. ${ }^{52}$ SSPs also create an environment of compassion and care for people who use drugs, ${ }^{53}$ which can lead to better health outcomes. ${ }^{54}$

The primary reason that friends and family members of individuals experiencing an overdose avoid contacting emergency services is the fear of criminal prosecution for themselves and the person experiencing the overdose. ${ }^{55}$ Overdose immunity protections provide criminal immunity from prosecution for certain crimes to individuals experiencing an overdose or bystanders to the overdose when they contact emergency services. ${ }^{56}$ Overdose immunity laws increase usage of emergency services and prevent overdoses. ${ }^{57}$

Naloxone and drug testing kits are other tools to reduce overdose and overdose deaths. Naloxone is an overdose reversal drug that can be used to block

50 Trang Quynh Nguyen et al., Syringe Exchange in the United States: A National Level Economic Evaluation of Hypothetical Increases in Investment, 18 AIDS BEHAVS. 2144, 2144 (2014).

${ }^{51}$ See, e.g., Curtis Hill, Handing Out Syringes to Addicts Is a Perilous Path, CURTIS HILL FOR IND. (Aug. 9, 2019), http://www.curtishillforindiana.com/opinions (scroll to opinion and click "Continue Reading") [https://perma.cc/R5L5-9H88].

52 See generally NAT'L Research Council, InSt. OF MED., PREventing HIV Transmissions: The Role OF STERILE NEEDLES AND BlEACH (Jacques Normand et al. eds., 1995) (finding that needle exchange programs do not increase the use of drugs); Melissa A. Marx et al., Trends in Crime and the Introduction of a Needle Exchange Program, 90 AM. J. Pub. HeAlth 1933, 1934 (2000) (refuting that needle exchange programs raise crime rates, with empirical data).

53 TERRY ET AL., supra note 1 , at 29.

54 Kim Sue (@DrKimSue), TwITTER (Feb. 8, 2019), https://twitter.com/DrKimSue/ status/1094025140004970497 [https://perma.cc/P2NY-9Z3X].

55 See Preventing the Consequences of Opioid Overdose: Understanding 911 Good Samaritan Laws, SAMHSA's CTR. FOR APPliCATION OF PREVENTION TeChS. 1, 5 (Nov. 2017), https://mnprc.org/wp-content/uploads/2019/01/good-samaritan-law-tool.pdf [https://perma.cc/64M6-VUQD] [hereinafter Preventing the Consequences of Opioid Overdose]; Karin E. Tobin et al., Calling Emergency Medical Services During Drug Overdose: An Examination of Individual, Social and Setting Correlates, 100 ADDICTION 397, 397-98 (2005); see also Zach Myers, Police Urge People to Call 911 to Report Overdoses Despite Risk of Arrest, FOX59 (May 15, 2017), http://fox59.com/2017/05/15/policeurge-911-calls-for-overdoses-despite-risk-of-arrest/ [https://perma.cc/U76N-P4Q3] (discussing fears of calling the police in a community where multiple overdoses have occurred).

56 Good Samaritan Overdose Prevention Laws, PRESCRIPTION DRUG ABUSE PoliCy SYS. (July 1, 2018), http://pdaps.org/datasets/good-samaritan-overdoselaws-150169 5153 [https://perma.cc/R977-LF8Z].

${ }^{57}$ Chandler McClellan et al., Opioid-Overdose Laws Association with Opioid Use and Overdose Mortality, 86 ADDICTIVE BEHAVs. 90, 90 (2018) (showing that Good Samaritan laws reduce the amount of opiate overdose deaths). 
the effects of opioids. ${ }^{58}$ Improved access to naloxone has resulted in thousands of overdose reversals. ${ }^{59}$ Drug testing kits can be used to test for the presence of the highly deadly, synthetic opioid, fentanyl in a drug. ${ }^{60}$ Test kits allow people who use drugs to avoid tainted supplies and prevent overdose. ${ }^{61}$ As outlined in Part II, the laws used to support these harm reduction strategies vary significantly from state to state.

Safe consumption sites, also referred to as overdose prevention sites and supervised injection facilities, are locations where people who use drugs can consume these drugs in a safe location supervised by trained individuals or health care professionals. ${ }^{62}$ Safe consumption sites have been found to reduce incidences of overdose deaths and ambulance calls. ${ }^{63}$ These facilities reduce public injecting and the disposal of syringes in public spaces. ${ }^{64}$ Not a single overdose death has occurred at a safe consumption site. ${ }^{65}$

\section{HARM REDUCTION LAWS IN THE UNITED STATES}

Much authority for public health interventions lies with state governments rather than the federal government. ${ }^{66}$ States are increasingly passing laws

58 Information About Naloxone, U.S. FOOD \& DRUG ADMIN. (Mar. 7, 2018), https://www.fda.gov/drugs/postmarket-drug-safety-information-patients-andprovide rs/information-about-naloxone [https://perma.cc/9UNL-83R8].

${ }^{59}$ See McClellan et al., supra note 57, at 90.

${ }^{60}$ Fentanyl, HARM REDUCTION COALITION, https://harmreduction.org/issues/ fentanyl/ [https://perma.cc/H5TF-HJJK].

61 Jacqueline E. Goldman et al., Perspectives on Rapid Fentanyl Test Strips as a Harm Reduction Practice Among Young Adults Who Use Drugs: A Qualitative Study, 16 HARM Reduction J. 3, 5 (2019). See generally Olga Khazan, The \$1 Tool that Might Curb the Overdose Epidemic, ATLANTIC (Oct. 3, 2018), https://www.theatlantic.com/health/ archive/2018/10/study-shows-fentanyl-test-stripskeep-addicts-safe/571981/ [https:// perma.cc/T6JS-2N2U] (describing the benefits of the use of fentanyl test strips by opioid users).

62 Supervised Consumption Services, DRUG POL'Y All. (Aug. 6, 2018), http://www.drugpolicy.org/issues/supervised-consumption-services [https://perma.cc /2XLY-TCCY].

63 Jennifer Ng et al., Does Evidence Support Supervised Injection Sites?, 63 CAN. FAM. PHYSICIAN 866, 866 (2017).

${ }^{64}$ See generally Tim Rhodes et al., Public Injecting and the Need for 'Safer Environment Interventions' in the Reduction of Drug-Related Harm, 101 ADDICTION 1384, 1388 (2006) (proposing solutions to the danger of public drug-injecting).

65 Suchitra Rajagopalan, Providing a Safe Space to Use Drugs Can Help End the Overdose Crisis, DRUG POL'Y ALL. (Sept. 10, 2018), http://www.drugpolicy. $\mathrm{org} / \mathrm{blog} /$ providing-safe-space-use-drugs-can-help-end-overdose-crisis [https://perma .cc/V4T9-ZXAB].

${ }^{66}$ See Richard A. Goodman et al., The Structure of Law in Public Health Systems and Practice, in Law in Public Health Practice 45, 58-62 (Richard A. Goodman et al. eds., 2 d ed. 2007). 
supporting harm reduction strategies, including naloxone access, ${ }^{67}$ syringe service programs, ${ }^{68}$ and overdose immunity laws. ${ }^{69}$ Yet, as this section will show, there remain many states that have not utilized these strategies, and there is much variability in the scope of existing state laws. ${ }^{70}$

States that have been the epicenter of the crisis, like West Virginia and Indiana, have seen closures of their syringe exchange programs due to pushback from policymakers and the community. ${ }^{71}$ But there has been so much focus on just getting harm reduction programming at all that there is a gap in utilizing legal strategies to support the effective implementation of these strategies. The sections below provide examples regarding the varied implementation of several harm reduction approaches.

\section{A. Syringe Service Programs}

Indiana's syringe service program law provides an example of an inadequate harm reduction law. Following the HIV outbreak in Scott County, Indiana, ${ }^{72}$ Indiana passed a temporary measure to allow for syringe exchange programs to operate in the county, ${ }^{73}$ which was made permanent and extended to allow for SSPs across the state. ${ }^{74}$ The 2015 law allows local governments to create syringe service programs following Hepatitis C and HIV epidemics that occurred because of injection drug use. ${ }^{75}$ The law does not allow for the creation

${ }^{67}$ Naloxone Overdose Prevention Laws, PRESCRIPTION DRUG ABUSE POL'y SYS. (July 1, 2017), http://pdaps.org/datasets/laws-regulating-administration-of-naloxone-1501 695139 [https://perma.cc/7FGB-WTGU].

68 See Austin Coleman, Needle Exchange Legality by State, CounCIL STATE Gov'TS (June 25, 2015), http://knowledgecenter.csg.org/kc/content/needle-exchange-legalitystate [https://perma.cc/YPC6-NZWP] ("Sixteen states have passed laws explicitly authorizing needle exchange programs, and there are a number of states with statutes that either decrease barriers to the distribution of clean needles or altogether remove syringes from the list of drug paraphernalia."). But see Josh Katz, Why a City at the Center of the Opioid Crisis Gave Up a Tool to Fight It, N.Y. TIMES (Apr. 27, 2018), https://www.nytimes.com/interactive/2018/04/27/upshot/charleston-opioid-crisis-

needle-exchange.html [https://perma.cc/5U9N-EPKN] (discussing the closure of a "successful" Charleston needle exchange program, "even as dozens of others have opened").

${ }^{69}$ See Good Samaritan Overdose Prevention Laws, supra note 56.

${ }^{70}$ See infra Parts III.A-D.

${ }^{71}$ See Katz, supra note 68.

${ }^{72}$ See Shari Rudavsky, An Indiana Town Recovering from 190 HIV Cases, INDIANAPOLIS STAR (Apr. 11, 2016), https://www.indystar.com/story/news/2016/04/08/ year-after-hiv-outbreak-austin-still-community-recovery/82133598/ [https://perma.cc /PUZ8-NXZZ].

${ }^{73}$ Press Release, State of Indiana, Needle Exchange for Scott County Only Now in Effect (Apr. 4, 2015) (on file with author).

${ }^{74}$ Ind. CODE ANN. $§ 16-41-7.5$ (West Supp. 2015).

${ }^{75} \mathrm{Id}$. 16-41-7.5-5. 
of an SSP in order to prevent an epidemic from occurring, a primary goal of public health. ${ }^{76}$

Programs are only able to operate for two years at a time. ${ }^{77}$ In order to keep operating, the SSP must secure renewal from the local government. ${ }^{78}$ This twoyear operation period has led to SSPs shutting down when unable to secure political support, ${ }^{79}$ particularly given the conservative climate within the state. ${ }^{80}$ In a state with ninety-two counties, ${ }^{81}$ only nine counties are operating SSPs. ${ }^{82}$

Although Indiana law authorizes the establishment of SSPs, it fails to provide sufficient legal protections to make them effective. The Indiana Court of Appeals affirmed the conviction of a man for drug paraphernalia possession who secured the paraphernalia, a syringe, from an SSP. ${ }^{83}$ The court said,

Thus, while [the defendant] could not be prosecuted for obtaining hypodermic needles from a needle exchange or participating in a needle exchange program, he could be found guilty of possession of paraphernalia if there was evidence that he intended to use those syringes for unlawful ends. ${ }^{84}$

Neither Indiana's SSP law nor its drug paraphernalia law provide immunity from drug paraphernalia possession for possessing a syringe from an SSP. ${ }^{85}$ And, although first-time drug paraphernalia possession is a misdemeanor in the state, ${ }^{86}$ the legislature passed a law escalating syringe possession to a felony in 2015.87

${ }^{76} I d$. (allowing a qualified entity to operate a syringe exchange program only if the relevant state officials have declared that there is presently an epidemic of Hepatitis $\mathrm{C}$ or HIV); What Is Public Health?, AM. PUB. HEALTH Ass'N, https://www.apha.org/what-ispublic-health [https://perma.cc/X8JK-2TYM].

$77 \S 16-41-7.5-11$.

78 Id.

${ }^{79}$ See Leigh Hedger, 2nd Indiana County Ends Needle Exchange, with 1 Official Citing Moral Concerns, INDIANAPOLIS STAR (Oct. 26, 2017), https://www.indystar.com/ story/news/2017/10/23/2nd-indiana-county-ends-needle-exchange-one-official-citing -moral-concerns/787740001 [https://perma.cc/UG6K-KF7B] (describing the closure of a needle exchange program in Lawrence County after the county prosecutor and state attorney general made their objections public).

${ }^{80}$ See generally Hill, supra note 51.

${ }^{81}$ County List, IND. DEP'T CHILD SERVS., https://www.in.gov/dcs/3204.htm [https://perma.cc/H8SR-SG4Q].

82 Syringe Service Program Providing Counties, InD. St. DeP'T HeAlth (July 18, 2018), https://www.in.gov/isdh/files/SSP\%20Map\%20-\%20July\%202018-EC.pdf [https://perma.cc/7HCW-JVWE].

${ }^{83}$ Leatherman v. State, 101 N.E.3d 879, 886 (Ind. Ct. App. 2018).

${ }^{84}$ Id.

85 See IND. CODE ANN. $§ 16-41-7.5$ (West Supp. 2015) (showing that no provision of the Syringe Exchange Program includes any criminal immunities); IND. CODE ANN. § 35-484-8.3 (West 2012).

${ }^{86}$ See § 35-48-4-8.3.

87 \$ $16-42-19-18$. 
Requirements of an emergency, the two-year duration, the risk of criminal liability, and the actual prosecution of syringe possession limit the efficacy of these programs. Indiana is one of twenty-five states that do not provide criminal immunity for possessing drug paraphernalia for the prevention of bloodborne infections. 88

\section{B. Overdose Immunity}

Like SSPs, overdose immunity protections are also implemented at the state level and vary substantially across jurisdictions. ${ }^{89}$ In Indiana, immunity is provided for the arrest and prosecution of drug and paraphernalia possession. ${ }^{90}$ Unlike a jurisdiction like Nevada, which provides protections for violations of parole and probation, ${ }^{91}$ Indiana fails to offer any additional protections. ${ }^{92}$ And Indiana's protection is only available for the bystander contacting emergency services, not the person experiencing the overdose. ${ }^{93}$ Yet, as outlined above, bystanders also fear the criminal prosecution of their loved one and thus avoid contacting emergency services. ${ }^{94}$ Additionally, the bystander can only secure the protection if they administer naloxone, ${ }^{95}$ thus limiting the protection to those that have access to the drug. In a February 2019 email to a listserv of public defenders in Indiana, one person emailed the group with the subject "calling 911 for overdose" and asked which statute gave the "fake protection." 96

Ohio also provides an instructive example. The state's overdose immunity law provides immunity from the arrest, charging, and prosecution of drug

88 Syringe Distribution Laws, POL'y SuRVeIllance ProjeCt (July 1, 2017), http://lawatlas.org/datasets/syringe-policies-laws-regulating-non-retail-distributionof-drug-parapherna [https://perma.cc/4V8Y-E2UJ] (examining the question, "[i]f syringes are defined as illegal drug paraphernalia, are there exceptions to the law that would allow for the distribution of syringes to prevent blood-borne diseases?" and finding that twenty-five states, including Indiana, have no such exception for syringe exchange programs).

${ }^{89}$ See Good Samaritan Overdose Prevention Laws, supra note 56 (showing that, among the forty-six states with drug overdose Good Samaritan laws, there is variation both in the scope of protections for overdose bystanders and the nature of those protections, e.g., immunities, affirmative defenses, or mitigating factors).

${ }^{90}$ IND. CODE ANN. § 16-42-27-2(g)-(h) (West 2019).

91 NEV. REV. STAT. ANN. § 453C.150 (LexisNexis Supp. 2016).

92 See Legal Interventions to Increase Access to Naloxone in Indiana Fact Sheet, NETwORK FOR PUB. HEALTH L. 2 (Mar. 2018), https://www.networkforphl.org/_asset/tw9 n11/Overdose-Prevention-Fact-Sheet.pdf [https://perma.cc/4RTK-D2YA] [hereinafter Legal Interventions] (stating that the only overdose immunity law for Indiana is contained within its law protecting access to overdose intervention drugs).

93 § 16-42-27-2(g)-(h).

94 See Preventing the Consequences of Opioid Overdose, supra note 55, at 1.

95 § 16-42-27-2(g)-(h).

96 Posting to Public Defender Council Mailing List, defendnet@lists.in.gov (Feb. 8, 2019) [on file with Ohio State Law Journal]. 
possession..$^{97}$ However, the law provides no immunity for drug paraphernalia possession..$^{98}$ Many drugs require paraphernalia in order to be consumed and thus the law fails to eliminate the risk of criminal liability, the primary reason for which emergency services are not called during an overdose. ${ }^{99}$

Some jurisdictions have also prosecuted friends and family members of overdose victims for drug-induced homicide if they supplied the drugs that led to the overdose. ${ }^{100}$ Overdose immunity laws fail to provide protections to these bystanders against homicide charges. ${ }^{101}$

\section{Naloxone and Drug Testing Kits}

Naloxone and drug testing kits, such as fentanyl test kits, prevent overdoses and overdose deaths. ${ }^{102}$ Yet, in some jurisdictions, they are considered drug paraphernalia, are regularly confiscated by law enforcement, and subject the possessor to criminal liability. ${ }^{103}$ Tennessee, for example, makes it illegal:

[F]or any person to use, or to possess with intent to use, drug paraphernalia to plant, propagate, cultivate, grow, harvest, manufacture, compound, convert, produce, process, prepare, test, analyze, pack, repack, store, contain, conceal, inject, ingest, inhale, or otherwise introduce into the human body a controlled substance or controlled substance analogue in violation of this part. ${ }^{104}$

In an effort to promote the use of drug testing kits, some jurisdictions have passed laws legalizing their use. ${ }^{105}$ For example, a recent bill passed in Colorado

97 OHIO Rev. Code ANN. § 2925.11 (West Supp. 2018).

98 Id. $\S 2925.14$.

${ }^{99}$ See, e.g., Preventing the Consequences of Opioid Overdose, supra note 55, at 5 (noting that individuals who are aware of Good Samaritan laws may still hesitate to call emergency services due to "skepticism and lack of trust" that they will really avoid criminal liability).

${ }^{100}$ Leo Beletsky, America's Favorite Antidote: Drug-Induced Homicide in the Age of the Overdose Crisis, 2019 UtAH L. ReV. 833, 873-74 (2019).

${ }^{101}$ Corey Davis et al., State Approaches to Addressing the Overdose Epidemic: Public Health Focus Needed, 47 J.L. MED. \& ETHICs 43, 44 (2019).

${ }^{102}$ Lucas Marten, Investigation: Where Are Naloxone Confiscations Happening the Most?, FILTER (Mar. 6, 2019), https://filtermag.org/2019/03/06/investigation-where-arenaloxone-confiscations-happening-the-most/ [https://perma.cc/B3AJ-BLX6] ("[Naloxone] simply saves lives, and has already saved tens of thousands in the US."); Fentanyl Test Strips Prove Useful in Preventing Overdoses, Brown U. (Oct. 18, 2018), https://www.brown.edu/news/2018-10-18/fentanyl [https://perma.cc/CX6S-L5PJ].

103 Marten, supra note 102.

104 TENn. CoDE ANN. § 39-17-425 (2014).

105 S.B. 19-227, 72d Gen. Assemb., 1st Reg. Sess. (Colo. 2019); see, e.g., Council of the District of Columbia Votes to Allow Life-Saving Drug Checking Kits, DRUG POL'Y ALL. (Dec. 5, 2017), http://www.drugpolicy.org/ press-release/2017/12/council-districtcolumbia-votes-allow-life-saving-drug-checking-kits [https://perma.cc/3S4Y -7522] (keeping drug testing equipment on the list of prohibited paraphernalia but creating 
specifies that drug paraphernalia does not include testing equipment to analyze a controlled substance. ${ }^{106}$

\section{Safe Consumption Sites}

Safe consumption sites (SCSs), often referred to as "safe injection facilities," generally serve injectable drug users. ${ }^{107}$ Safe consumption sites provide safe, sterile supplies for drug use. ${ }^{108}$ The staff, often but not always, are healthcare providers that can provide resources and answer questions about safer consumption strategies. ${ }^{109}$ Staff also can provide health care services such as first aid, monitoring for overdoses, and administering overdose intervention drugs. ${ }^{110}$ SCSs may link folks to other social services and health care services. ${ }^{111}$

These sites are legal in various countries around the world, including Canada and Germany. ${ }^{112}$ As numerous local governments across the country have begun discussing and planning for establishing safe consumption sites in the United States, ${ }^{113}$ the federal government's position has been that these sites are illegal under federal law. ${ }^{114}$ Specifically, the U.S. Department of Justice

an exemption for syringe exchange organizations to distribute kits and for individual users to check their personal drugs).

106 Colo. S.B. 19-227.

107 Supervised Consumption Services, supra note 62.

${ }^{108}$ Leo Beletsky et al., The Law (and Politics) of Safe Injection Facilities in the United States, 98 AM. J. PuB. HeAlTh 231, 231 (2008).

${ }^{109}$ Id.

${ }^{110} I d$.

${ }^{111} I d$.

112 Supervised Consumption Services, supra note 62.

113 Jessica Cohen, Supervised Injection Facilities Face Obstacles, but that Shouldn't Stop Them, HEAlTH AFFAIRS BLOG (Nov. 29, 2018), https://www.healthaffairs.org/do/10.1377/hblog20181127.121405/full/ [https://perma .cc/9GRR-DGNH].

${ }^{114}$ Press Release, Dep't of Justice U.S. Attorney's Office District of Colo., Joint Statement of the U.S. Attorney's Office and the Denver Field Office of the Drug Enforcement Administration Regarding the City and County of Denver's Proposal to Create Supervised Locations to Inject Heroin and Other Illegal Drugs (Dec. 4, 2018), https://www.justice.gov/usao-co/pr/joint-statement-us-attorney-s-office-and-denverfield-office-drug-enforcement [https://perma.cc/PK7P-M3X9] (stating that there could be civil and criminal penalties for "anyone that knowingly opens, leases, rents, maintains, or anyone that manages or controls and knowingly and intentionally makes available such premises for use"); Press Release, Dep't of Justice U.S. Attorney's Office District of Vt., Statement of the U.S. Attorney's Office Concerning Proposed Injection Sites (Dec. 13, 2017), https://www.justice.gov/usao-vt/pr/statement-us-attorney-s-office-concerningproposed-injection-sites [https://perma.cc/326N-KFFE] (stating that safe injection facilities "would violate several federal criminal laws, including those prohibiting use of narcotics and maintaining a premises for the purpose of narcotics use"). 
argues that these sites violate the "crack house statute," 115 which prohibits the operating of a site where drugs are used. ${ }^{116}$ At the state level, a safe consumption site would be unlawful under existing drug and paraphernalia possession laws. ${ }^{117}$

The federal government recently sued Safehouse, a Pennsylvania nonprofit that seeks to offer overdose prevention services at a safe consumption site, ${ }^{118}$ for declaratory relief stating that the operation of an SCS violates federal law. ${ }^{119}$ The suit is pending in the U.S. District Court for the Eastern District of Pennsylvania. ${ }^{120}$ In its Answer, Safehouse argues that it is not violating federal law because an SCS is a medical and public health facility, distinguishable from the crack house targeted by federal law. ${ }^{121}$

\section{CONCLUSION}

Upticks in opioid use disorder and overdose over the past decades are coupled with increased rates of methamphetamine and cocaine use across several communities around the country. ${ }^{122}$ Clay Marsh, leaning on research from Anne Case and Angus Deaton, ${ }^{123}$ argues that the opioid crisis is a symptom

115 Alex Kreit, Safe Injection Sites and the Federal “Crack House” Statute, 60 B.C. L. REV. 413, 418 (2019).

11621 U.S.C. $\$ 856$ (2012).

${ }^{117}$ Kreit, supra note 115, at 418 ("The United States Attorneys for the districts of Colorado, Massachusetts, and Vermont have announced that if safe injection sites were established in their states, they would consider bringing criminal charges against facility employees.").

118 About, SAFEHOUSE, https://www.safehousephilly.org/about [https://perma.cc/ Z34D-NG3E].

${ }^{119}$ Complaint at 2, United States v. Safehouse, No. 2:19-cv-00519-GAM (E.D. Pa. Feb. $5,2019)$.

120 Id.

${ }^{121}$ Defendant's Answer at 5, United States v. Safehouse, No. 2:19-cv-00519-GAM (E.D. Pa. Apr. 3, 2019).

122 See What Is the Scope of Methamphetamine Misuse in the United States? NAT'L INST. ON DRUG ABUSE, https://www.drugabuse.gov/publications/research-reports/ methamphetamine/what-scope-methamphetamine-misuse-in-united-states [https://per ma.cc/VX2B-J65Z] (last updated Apr. 2019) (describing the rise in methamphetamine use); Chloe Reichel, Cocaine Use Is on the Rise: Research Highlights Troubling Trends, JOURNALIST'S RES. (May 28, 2019), https://journalistsresource.org/studies/society/ public-health/cocaine-research-fentanyl-overdose/ [https://perma.cc/U3LZ-8UN4] (detailing the recent rise of cocaine use).

123 See generally Anne Case \& Angus Deaton, Mortality and Morbidity in the 21st Century, BROOKINGS PAPERS ON ECON. ACTIVITY 397 (2017), https://www.brook ings.edu/wp-content/uploads/2017/08/casetextsp17bpea.pdf [https://perma.cc/H62B$\mathrm{P} 4 \mathrm{HB}$ ] (finding that "mortality and morbidity among white non-Hispanic Americans in midlife since the turn of the century continued to climb through 2015 " in part due to an increase in drug overdoses). 
of a larger crisis. ${ }^{124}$ Really, the crisis's root causes stem from the social determinants of health-poverty, education, housing. ${ }^{125}$ Policies addressing these social determinants are complex and require significant policy and system change. ${ }^{126}$ In the meantime, harm reduction measures exist that can save lives. ${ }^{127}$

While there have been significant increases in states' legislative action supporting harm reduction strategies, many of these laws are narrow in application or fail to close loopholes that undermine the efficacy of these laws. State legislatures need to ensure that when they legislate on these issues, the laws are structured in a way that actually supports these strategies.

I have previously argued that "there are actionable, discrete, evidence-based policy measures" to respond to the opioid overdose crisis that are being undermined by ineffective legislation. ${ }^{128}$ But in fact, harm reduction is not simply undermined but instead has not been legalized in many jurisdictions. Meaningful changes to harm reduction laws must be made in conjunction with social and structural determinants before real improvements to the opioid use disorder and overdose crisis are made.

${ }^{124}$ See generally Clay Marsh, Opioid Addiction Isn't the Disease; It's the Symptom, HuFfPost (June 16, 2017), https://www.huffpost.com/entry/opioid-addiction-isnt-thedisease-its-the-symptom_b_59441bc3e4b06bb7d272e3b6 [https://perma.cc/X3N33TXT] ("The answer to our opioid epidemic, then, is the same as the answer to our increasing health care spending and reduced health and lifespan of our population.... We need strong connections to others.").

125 See Dasgupta et al., supra note 21, at 183.

126 See id. at 182.

127 See supra Parts I, II.

128 Aila Hoss, Many State Laws Undermine Harm Reduction Strategies in the Opioid Crisis, BILl OF HeAlth: HARV. L. Petrie-Flom CTR. (July 20, 2018), http://blogs.harvard.edu/billofhealth/2018/07/20/many-state-laws-undermine-harmreduction-strategies-in-the-opioid-crisis/ [https://perma.cc/LD76-45YS]. 